\title{
Corpus Luteum
}

National Cancer Institute

\section{Source}

National Cancer Institute. Corpus Luteum. NCI Thesaurus. Code C26465.

A group of cells that remain of the Graafian follicle following ovulation. This structure is composed of endocrine tissue and produces progesterone. This is needed to prepare the uterine lining for implantation by the fertilized egg. 